\title{
Identification of the covalently bound flavins of D-gluconate dehydrogenases from Pseudomonas aeruginosa and Pseudomonas fluorescens and of 2-keto-D-gluconate dehydrogenase from Gluconobacter melanogenus
}

\author{
William McINTIRE,* Thomas P. SINGER, ${ }^{*} \uparrow$ Minoru AMEYAMA, $\ddagger$ Osao ADACHI, \\ Kazunobu MATSUSHITA $\ddagger$ and Emiko SHINAGAWA $\ddagger$ \\ *Molecular Biology Division, Veterans Administration Medical Center, San Francisco, CA 94121, U.S.A., †Department of \\ Biochemistry and Biophysics and †Department of Pharmaceutical Chemistry, University of California, San Francisco, CA \\ 94143, U.S.A., and †Department of Agricultural Chemistry, Faculty of Agriculture, Yamaguchi University, Yamaguchi, Japan
}

An improved method is presented for the purification of $8 \alpha-\left(N^{1}\right.$-histidyl)riboflavin, $8 \alpha-\left(N^{3}\right.$-histidyl)riboflavin and their $2^{\prime}, 5^{\prime}$ - anhydro forms, which permits the isolation of sizeable quantities of each of these compounds from a synthetic mixture in pure form. Flavin peptides were isolated from the D-gluconate dehydrogenases of Pseudomonas aeruginosa and Pseudomonas fluorescens and from the 2-keto-D-gluconate dehydrogenase of Gluconobacter melanogenus. After conversion into the aminoacyl-riboflavin, the flavin in all three enzymes was identified as $8 \alpha-\left(N^{3}\right.$-histidyl)riboflavin. By sequential treatment with nucleotide pyrophosphatase and alkaline phosphatase, the flavin in each enzyme was shown to be in the dinucleotide form.

\section{INTRODUCTION}

Since the structure of the first covalently bound flavin, the prosthetic group of succinate dehydrogenase, was elucidated 15 years ago (Walker \& Singer, 1970), five different types of covalently bound flavin have been identified in over 25 enzymes. Despite extensive studies in many laboratories, no relation has been found between the catalytic function of an enzyme and whether or not it will contain covalently bound flavin and, if so, what type. Thus, although the flavin components of some enzymes that function in non-phosphorylating carbohydrate metabolism in micro-organisms have been identified (Kenney et al., 1979; Harada et al., 1979), when several membrane-bound bacterial enzymes involved in gluconate metabolism were isolated and shown to contain covalently bound flavin (Matsushita et al., 1979a, 1982; Shinagawa et al., 1981) it was necessary to characterize their prosthetic groups.

The enzymes investigated in the present study, D-gluconate dehydrogenase from Pseudomonas aeruginosa and Pseudomonas fluorescens and 2-keto-D-gluconate dehydrogenase from Gluconobacter melanogenus, are of interest to us because of their unusual properties. All three are flavocytochromes and contain per mol $1 \mathrm{~mol}$ each of flavoprotein, a $c$-type cytochrome and a colourless low- $M_{\mathrm{r}}$ subunit of unknown function, which seems to be an essential constituent (Matsushita et al., 1979a; Shinagawa et al., 1981). The two gluconate dehydrogenases are also unusual because their cytochrome subunit is reported to contain two haem groups (Matsushita $e t$ al., 1982). This raises the interesting question whether electron transport from the flavin to ubiquinone (Matsushita et al., 1979b) involves both haem groups and, if so, whether they act in tandem or sequentially. As a first step in defining the function of the component subunits of these enzymes, a collaboration between the laboratories in San Francisco and Yamaguchi was undertaken to characterize the covalently. bound flavins. The present paper is an account of this work.

\section{EXPERIMENTAL}

\section{Materials}

D-Gluconate dehydrogenase from Ps. aeruginosa and from Ps. fluorescens, and 2-keto-D-gluconate dehydrogenase from Gluconobacter melanogenus were purified as previously described (Matsushita et al., 1979a, 1982; Shinagawa et al., 1981). The pure proteins were precipitated with $\left(\mathrm{NH}_{4}\right)_{2} \mathrm{SO}_{4}$ in the presence of cholic acid, centrifuged, dried in vacuo and stored at $-20^{\circ} \mathrm{C}$.

The phosphocellulose was obtained from the GallardSchlesinger Chemical Mfg. Corp., analytical cellulose thin-layer plates (F1440) were from Schleicher and Schuell, and preparative cellulose Uniplates $(250 \mu \mathrm{m}$

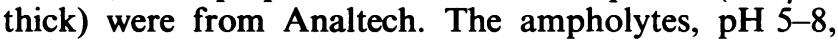
and the Sephadex G-200 (superfine grade) were from Pharmacia Fine Chemicals. Octadecylsilane-modified silica gel (flash-chromatography grade, $40 \mu \mathrm{m}$ particle size) was manufactured by the J. T. Baker Chemical Co. The analytical octadecylsilane-bonded silica-gel (ODSSpherogel, $3 \mu \mathrm{m}$ particle size) column $(4.6 \mathrm{~mm} \times 75 \mathrm{~mm})$ was from Beckman Instruments. Crystallized bovine trypsin and chymotrypsin were purchased from the Worthington Biochemical Corp., and Escherichia coli alkaline phosphatase and Crotalus atrox nucleotide pyrophosphatase were from Sigma Chemical Co.

\section{Synthesis and purification of histidyl-flavins}

A mixture of $8 \alpha-\left(N^{1}\right.$-histidyl)-, $8 \alpha-\left(N^{3}\right.$-histidyl)-, $2^{\prime}, 5^{\prime}$-anhydro- $8 \alpha-\left(N^{\prime}\right.$-histidyl)- and $2^{\prime}, 5^{\prime}$-anhydro- $8 \alpha-$ 
( $N^{3}$-histidyl)-riboflavins was synthesized as previously described (Walker et al., 1972). A solution of the crude mixture $(1.6 \mathrm{mmol}$ of flavin) in $8 \%(\mathrm{v} / \mathrm{v})$ formic acid was applied to a $2.5 \mathrm{~cm} \times 20 \mathrm{~cm}$ phosphocellulose column, equilibrated with the same solution. Neutral flavins were washed off the column with the same formic acid solution, whereas the charged material remained bound. The column was washed with $5 \%(\mathrm{v} / \mathrm{v})$ acetic acid, and flavins held on the column were eluted with $5 \%(\mathrm{v} / \mathrm{v})$ pyridine and freeze-dried. A small amount of this material was purified by paper electrophoresis at $\mathrm{pH} 5.0$, with $5 \%(\mathrm{v} / \mathrm{v})$ pyridinium acetate. The mobilities relative to FMN were used to identify the various histidyl-flavins (Edmondson et al., 1976) and were used as standard throughout the remaining experiments. The individual histidyl-flavins were also subjected to h.p.l.c. analysis ( $3 \mu \mathrm{m}$-particle-size ODS-Spherogel column, $4.6 \mathrm{~mm} \times$ $75 \mathrm{~mm})$. The flow rate was $0.7 \mathrm{ml} / \mathrm{min}$ and the solvent $5 \mathrm{~mm}$-ammonium acetate $(\mathrm{pH} 4.8) /$ methanol $(21: 4, \mathrm{v} / \mathrm{v})$. Elution of flavins was monitored at $438 \mathrm{~nm}$. The same h.p.l.c. system was used in subsequent steps to monitor flavins.

The bulk of the material eluted from the phosphocellulose column was freeze-dried and then dissolved in a minimal volume of $1 \%(\mathrm{v} / \mathrm{v})$ acetic acid, and applied to a second phosphocellulose column $(2.5 \mathrm{~cm} \times 20 \mathrm{~cm})$ equilibrated with the same solvent. This was washed with $300 \mathrm{ml}$ of $1 \%$ acetic acid; then a linear gradient was applied, with $750 \mathrm{ml}$ of $1 \%$ acetic acid in the mixer and $750 \mathrm{ml}$ of $1 \%(\mathrm{v} / \mathrm{v})$ pyridine in the reservoir, $9.25 \mathrm{ml}$ fractions being collected. Histidyl-flavins were eluted in the $\mathrm{pH}$ range 5.9-6.8 in two peaks. Peak I (fractions 115-124) contained mostly $2^{\prime}, 5^{\prime}$-anhydro- $8 \alpha-\left(N^{3}\right.$-histidyl)riboflavin and peak II (fractions 125-135) mostly $8 \alpha-\left(N^{3}\right.$-histidyl)riboflavin, although each of these fractions contained significant amounts of the corresponding $N^{\mathbf{l}}$-histidyl isomer. The material collected in peak I and that in peak II were freeze-dried separately.

The flavin from peak I was dissolved in $4 \mathrm{ml}$ of 1:20-diluted Pharmalyte 5-8, mixed with a thick slurry of Sephadex G-200 (superfine grade) gel and applied in a $0.8 \mathrm{~cm} \times 20 \mathrm{~cm}$ trough in a bed of swollen Sephadex. The bed $(21.5 \mathrm{~cm} \times 21.5 \mathrm{~cm} \times 0.5 \mathrm{~cm})$ coilsisted of $8 \mathrm{~g}$ of washed Sephadex G-200 (superfine grade) preswollen in $250 \mathrm{ml}$ of water and $12.5 \mathrm{ml}$ of Pharmalyte 5-8 (Frey \& Rudola, 1982). (A detailed description of the preparation of the Sephadex and conditions for running the isoelectric focusing can be found in a pamphlet entitled 'Isoelectric Focusing, Principals and Methods' available from Pharmacia Fine Chemicals.) An electric field (25 W) was applied and the flavins were focused according to their $\mathrm{pI}$ values. The $\mathrm{pH}$ values along the gradient were determined by scooping out a small amount of the Sephadex, suspending it in water, centrifuging, and measuring the $\mathrm{pH}$. Four major bands developed and were separately processed. The material in peak II was treated identically and the same four bands appeared on electrofocusing.

Identical bands originating from peaks I and II were combined, and the flavin in each of the four bands was eluted with $5 \%(\mathrm{v} / \mathrm{v})$ acetic acid, filtered through a sintered-glass funnel and freeze-dried. Each of the resulting four samples was dissolved in a minimum volume of $5 \mathrm{~mm}$-ammonium acetate, $\mathrm{pH} 4.8$. The final step in purification was chromatography of each sample on a $1.5 \mathrm{~cm} \times 50 \mathrm{~cm}$ column of $40 \mu \mathrm{m}$-particle-size octadecylsilane-bonded silica-gel particles, with $5 \mathrm{~mm}-$ ammonium acetate $(\mathrm{pH} 4.8) /$ methanol $(89: 11, \mathrm{v} / \mathrm{v})$ as the eluent and a flow rate of $4 \mathrm{ml} / \mathrm{min}$. Monitoring absorbance at both 254 and $438 \mathrm{~nm}$ indicated that the ampholytes were eluted in the first $25 \mathrm{~min}$ and the flavins at about $50 \mathrm{~min}$. Comparison of the absorption spectra of each flavin with published data (McIntire et al., 1981) and analytical h.p.l.c. indicated that all four histidylriboflavins were pure.

\section{Purification of flavin peptides}

As a result of the isolation procedure (Matsushita $e t$ al., 1979a, 1982; Shinagawa et al., 1981), the enzyme preparations contained unknown amounts of poly(ethylene glycol), cholic acid and Triton X-100. It was therefore necessary to remove these agents as much as possible before proteolytic digestion. Samples of D-gluconate dehydrogenase from Ps. aeruginosa $(25 \mathrm{nmol})$ and from Ps. fluorescens $(22 \mathrm{nmol})$ and of 2-keto-D-gluconate dehydrogenase $(16 \mathrm{nmol})$ were suspended in $0.5 \mathrm{ml}$ of water, and each was twice extracted with chloroform/ methanol $(2: 1, \mathrm{v} / \mathrm{v})$. To each residue $0.55 \mathrm{ml}$ of $5.5 \%$ $(\mathrm{w} / \mathrm{v})$ trichloroacetic acid was added. The suspensions were centrifuged, each residue was suspended in $5 \mathrm{ml}$ of $1 \mathrm{M}$-Tris base and re-centrifuged, each pellet was again suspended in $0.5 \mathrm{ml}$ of $75 \mathrm{~mm}$-Tris/ $\mathrm{HCl}$ buffer, $\mathrm{pH} \mathrm{7.6,}$ and $5 \mathrm{mg}$ each of trypsin and chymotrypsin were added, along with a drop of toluene to retard bacterial growth.

Each of the samples was incubated for $18 \mathrm{~h}$, at which time $3 \mathrm{mg}$ more of each proteolytic enzyme was added and digestion continued for another $24 \mathrm{~h}$. This long digestion was required because of the unusual resistance of these membrane enzymes to proteolysis. The turbid solutions were centrifuged and the reddish pellets discarded. To the supernatant solutions $50 \mu \mathrm{l}$ of $55 \%$ $(w / v)$ trichloroacetic acid was added and centrifugation repeated. The resulting clear solutions were applied to $0.5 \mathrm{~cm} \times 5 \mathrm{~cm}$ Florisil columns, equilibrated with $5 \%$ $(v / v)$ acetic acid, washed with the same solution until the absorbance at $280 \mathrm{~nm}$ fell below 0.02 , then washed with water, and finally eluted with $20 \%(\mathrm{v} / \mathrm{v})$ pyridine. To remove Florisil carried over, each eluate was freeze-dried, resuspended in a small volume of $20 \%$ pyridine and centrifuged, and the pellets were washed twice with minimal volumes of $20 \%$ pyridine. The combined clear liquids were then freeze-dried.

For optimal separation of the FAD-containing peptides from Ps. aeruginosa and $G$. melanogenus by t.l.c., they were converted into the riboflavin level by successive treatments with $2 \mu \mathrm{l}$ of a $1 \mathrm{mg} / \mathrm{ml}$ solution of nucleotide pyrophosphatase in $50 \mathrm{~mm}-N$-ethylmorpholinium acetate

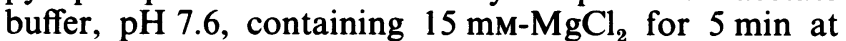
$37^{\circ} \mathrm{C}$, then with $2 \mu \mathrm{l}$ of a $1 \mathrm{mg} / \mathrm{ml}$ solution of alkaline phosphatase in $50 \mathrm{~mm}-N$-ethylmorpholinium acetate, $\mathrm{pH}$ 8.0 , for $5 \mathrm{~min}$.

The final step in purification of the flavin peptides from each dehydrogenase involved chromatography on $250 \mu \mathrm{m}$-thick cellulose thin-layer plates $(2.5 \mathrm{~cm} \times 20 \mathrm{~cm})$. Solvent system C (see below) was used for the peptides from $P$ s. aeruginosa and $G$. melanogenus and solvent system D for the Ps. fluorescens peptide. The major yellow and fluorescent band originating from each enzyme was scraped off. These bands were, in each case, well separated from the haem and most of the ninhydrinpositive bands. The cellulose was suspended in acetone, transferred to a small column, washed with acetone, and 
Table 1. Chromatographic properties and isoelectric-focusing characteristics of histidyl-flavins

The $\mathrm{p} K_{\mathrm{a}}$ values given refer to the imidazole nitrogen, as determined by the dependence of fluorescence on $\mathrm{pH}$ (Edmondson et al., 1976). The $R_{F}$ values in the last column were determined in solvent system $\mathrm{C}$.

\begin{tabular}{|c|c|c|c|c|c|}
\hline \multirow[b]{2}{*}{$8 \alpha$-Histidyl-flavin } & \multirow[b]{2}{*}{ pI } & \multirow[b]{2}{*}{$\mathrm{p} K_{\mathrm{a}}$} & \multicolumn{2}{|c|}{$\begin{array}{l}\text { Retention time in } \\
\text { h.p.l.c. (min) }\end{array}$} & \multirow[b]{2}{*}{$R_{F}$} \\
\hline & & & Solvent A & Solvent B & \\
\hline $\begin{array}{l}N^{3}- \\
2^{\prime}, 5^{\prime} \text {-anhydro- } N^{3}- \\
N_{-}^{1} \\
2^{\prime}, 5^{\prime} \text {-anhydro- } N^{1}-\end{array}$ & $\begin{array}{l}6.64 \\
6.46 \\
6.28 \\
6.00\end{array}$ & $\begin{array}{l}5.2 \\
5.0 \\
4.7 \\
4.5\end{array}$ & $\begin{array}{l}2.53 \\
2.70 \\
4.29 \\
4.35\end{array}$ & $\begin{array}{l}2.84 \\
3.00 \\
4.56 \\
4.42\end{array}$ & $\begin{array}{l}0.25 \\
0.28 \\
0.30 \\
0.32\end{array}$ \\
\hline
\end{tabular}

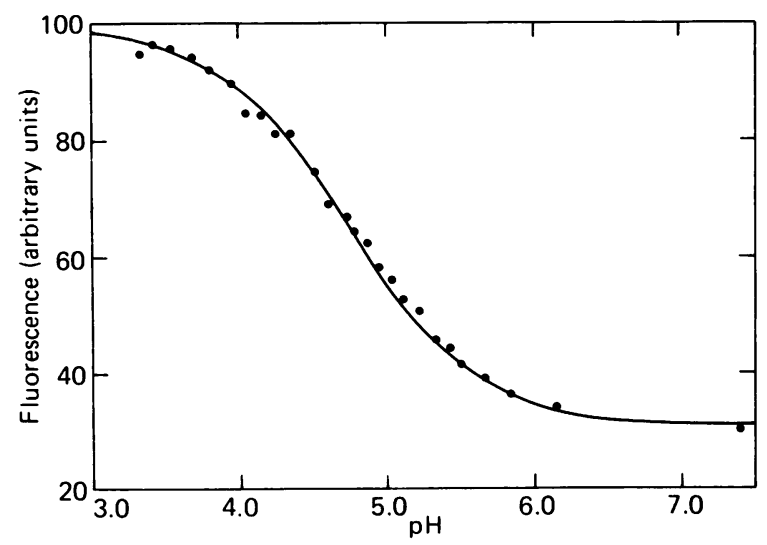

Fig. 1. Dependence of the fluorescence of the aminoacyl-fiavin from D-gluconate dehydrogenase on $\mathrm{pH}$

The aminoacyl-flavin was isolated from the dehydrogenase of Ps. aeruginosa, as described, and dephosphorylated to the riboflavin level. The flavin was dissolved in $3 \mathrm{ml}$ of $50 \mathrm{~mm}$-sodium acetate. The solution was titrated first with small portions of $5 \%(\mathrm{v} / \mathrm{v})$ acetic acid, then with $100 \%$ acetic acid. After each addition the $\mathrm{pH}$ and the fluorescence were measured. The symbols represent experimental points, corrected for volume change, and the continuous line is the computer fit to the Henderson-Hasselbach equation.

eluted with $20 \%(\mathrm{v} / \mathrm{v})$ pyridine. The resulting peptides were then freeze-dried.

\section{Generation of the aminoacyl-flavins}

The flavin peptide sample was placed in a hydrolysis tube, and $0.2 \mathrm{ml}$ of water and $0.2 \mathrm{ml}$ of $12 \mathrm{M}-\mathrm{HCl}$ were added. The tubes were evacuated, sealed, and incubated at $95^{\circ} \mathrm{C}$ for $16 \mathrm{~h}$. These conditions are not harsh enough to cause significant destruction of histidyl-flavins (Edmondson et al., 1976). The samples were freeze-dried and used without further purification.

\section{Other methods}

The fluorescence measurements were carried out in a Hitachi-Perkin-Elmer MPF-3 spectrofluorometer, and h.p.l.c. separations with an instrument manufactured by Altex Scientific. Effluents from h.p.l.c. were monitored either by absorbance or by fluorescence. In the latter case a Gilson Spectra/Glo fluorimeter, equipped with a 330-400 nm-excitation filter and a 460-600 nm-emission filter, was used. For isoelectric focusing the Pharmacia flat-bed apparatus (FBE 3000) was employed. Spectra were taken on a Cary 14 spectrophotometer interfaced to a Nova 2/4 computer. The $\mathrm{pH}$-fluorescence titration data were fitted by computer to the Henderson-Hasselbach equation by using a program that we have described (Kenney \& McIntire, 1983). The solvent systems used for h.p.l.c. were: A, $5 \mathrm{~mm}$-ammonium acetate $(\mathrm{pH}$ 4.8)/methanol $(21: 4, \mathrm{v} / \mathrm{v})$; B, $5 \mathrm{~mm}$-ammonium acetate $(\mathrm{pH} 4.8) /$ methanol $(3: 1, \mathrm{v} / \mathrm{v})$. The flow rate was $0.7 \mathrm{ml} / \mathrm{min}$ and the column a Beckman $3 \mu \mathrm{m}$-particlesize ODS-Spherogel. Solvent systems for t.l.c. were: C, pyridine/butan-1-ol/acetic acid/water (15:10:3:12, by vol.); D, butan-1-ol/acetic acid/water (12:3:5, by vol.). Analytical-grade cellulose was the supporting phase in each case.

\section{RESULTS AND DISCUSSION}

\section{Improved separation of synthetic histidylriboflavins}

Pilot experiments on a flavin peptide isolated from the D-gluconate dehydrogenase of Ps. fluorescens indicated that it is likely to contain a histidylriboflavin derivative, as judged from the $\mathrm{pH}$-dependence of its fluorescence. Identification of the particular isomer required the synthesis of pure $8 \alpha-\left(N^{1}\right.$-histidyl $)$ riboflavin and $8 \alpha-\left(N^{3}-\right.$ histidyl)riboflavin. Although their synthesis and separation from each other, as well as from their anhydro forms produced in the synthesis, has been described previously (Edmondson et al., 1976), the separation methods used in these earlier studies were limited to processing $2-5 \mu \mathrm{mol}$ of material because of the limited capacity of the paper-electrophoretic and paper-chromatographic methods used. Another disadvantage of these earlier methods was that the filter paper used as well as the kerosene coolant frequently introduced impurities, removal of which necessitated additional purification steps.

In searching for alternative separation methods we found chromatography in phosphocellulose columns in conjunction with isoelectric focusing ideal for the purpose. These techniques permitted processing $20-40 \mu \mathrm{mol}$ of histidyl-flavin at a time and resulted in complete separation of the four forms. A final reverse-phase h.p.l.c. step also had a high capacity for these compounds and resulted in complete removal of all detectable impurities. The four pure histidyl-flavins were then identified by comparison with standards prepared by the earlier procedure (Edmondson et al., 1976) from their respective electrophoretic mobilities.

\section{Properties of histidyl-flavins}

With substantial quantities of both isomers of histidylriboflavin and of their 2',5'-anhydro forms available, we determined their $\mathrm{pI}$ values, retention times on a reverse-phase h.p.l.c. column, and $R_{F}$ values in the t.l.c. systems in current use (Table 1). Assuming that the $\mathrm{p} K_{\mathrm{a}}$ values of the carboxy and $\alpha$-amino groups in the four compounds are the same, their pI values should increase with the $\mathrm{p} K_{\mathrm{a}}$ of the imidazole nitrogen. As seen in the Table, this proved to be the case. Significant differences in retention time in h.p.l.c. are also documented, whereas 
Table 2. Characteristics of the aminoacyl-flavins isolated from various dehydrogenases

The $R_{F}$ values in the last column were determined in solvent system C. Abbreviation: N.D., not determined

\begin{tabular}{|c|c|c|c|c|}
\hline \multirow[b]{2}{*}{ Source of aminoacyl-flavin } & \multirow[b]{2}{*}{$\mathrm{p} K_{\mathrm{a}}$} & \multicolumn{2}{|c|}{$\begin{array}{l}\text { Retention time in } \\
\text { h.p.l.c. }(\mathrm{min})\end{array}$} & \multirow[b]{2}{*}{$R_{F}$} \\
\hline & & Solvent A & Solvent B & \\
\hline $\begin{array}{l}\text { D-Gluconate dehydrogenase (Ps. aeruginosa) } \\
\text { D-Gluconate dehydrogenase (Ps. fluorescens) } \\
\text { 2-Keto-D-gluconate dehydrogenase (G. melanogenus) }\end{array}$ & $\begin{array}{l}4.74 \pm 0.01 \\
4.65 \pm 0.02 \\
4.68 \pm 0.02\end{array}$ & $\begin{array}{l}\text { N.D. } \\
4.31 \\
4.27\end{array}$ & $\begin{array}{l}4.54 \\
\text { N.D. } \\
\text { N.D. }\end{array}$ & $\begin{array}{l}\text { N.D. } \\
0.30-0.32 \\
0.30-0.32\end{array}$ \\
\hline
\end{tabular}

Table 3. $R_{F}$ values of flavin-containing peptides at the FAD, FMN and riboflavin level

\begin{tabular}{ccc}
\multicolumn{3}{c}{$R_{F}$ value } \\
As isolated pyrophosphatase & $\begin{array}{c}\text { After } \\
\text { pyrophosphatase } \\
\text { and phosphatase }\end{array}$ \\
\hline $0.12^{*}$ & $0.29^{*}$ & $0.13^{*}$ \\
$0.43^{\dagger}$ & $0.61 \dagger$ & $0.74^{\dagger}$ \\
$0.46^{*}$ & $0.68^{*}$ & $0.67^{*}$ \\
$0.14^{\dagger}$ & $0.24 \dagger$ & $0.16^{\dagger}$
\end{tabular}

* In solvent D.

+ In solvent $\mathrm{C}$.

the $R_{F}$ values of isomeric flavins in the t.l.c. system used are not markedly different.

\section{Identification of the aminoacyl-flavins}

At the outset of this study low yields in the proteolytic digestion step and resulting limitation of material available for analysis posed a problem that hampered positive identification of the type of flavin present in the three enzymes investigated here. This was traced to the hydrophobicity of these membrane-bound proteins (Matsushita et al., 1979a, 1982; Shinagawa et al., 1981). The procedure was revised, as described in the Experimental section, to overcome this problem, giving satisfactory yields, which were more than sufficient for unambiguous identification of the flavin.

The dependence of fluorescence on $\mathrm{pH}$ of the aminoacyl-flavins from all three dehydrogenases left no doubt that an $8 \alpha$-histidyl-flavin was present. A typical titration is shown in Fig. 1. Table 2 summarizes the $\mathrm{p} K_{\mathrm{a}}$ values and chromatographic behaviour of all three aminoacyl-flavins isolated at the riboflavin level. Comparison with the values for authentic samples in Table 1 proves beyond doubt that the compound isolated from all three dehydrogenases is $8 \alpha-\left(N^{3}\right.$-histidyl)riboflavin.

It remained to determine whether the flavin was present in these enzymes at the dinucleotide or mononucleotide level. To this end, the major flavin peptide from each enzyme was analysed by t.l.c. before and after treatment with nucleotide pyrophosphatase, which converts FAD-containing peptides into the corresponding FMN-containing peptides, and again after incubation with alkaline phosphatase to hydrolyse the
5 -phosphate group. The results, presented in Table 3, clearly show that the flavin is at the FAD level in all three dehydrogenases.

This investigation was supported by the Program Project HL16251 from the National Institutes of Health, by Grant PCM19609 from the National Science Foundation, and by the Veterans Administration.

\section{REFERENCES}

Edmondson, D. E., Kenney, W. C. \& Singer, T. P. (1976) Biochemistry 15, 2937-2945

Frey, M. D. \& Rudola, B. J. (1982) Electrophoresis 3, 216-225

Harada, Y., Shimizu, M., Murakawa, S. \& Takahashi, T. (1979) Agric. Biol. Chem. 43, 2635-2636

Kenney, W. C. \& McIntire, W. (1983) Biochemistry 22, 3858-3868

Kenney, W. C., Edmondson, D. E., Singer, T. P., Nishikimi, M., Nogudri, E. \& Yagi, K. (1979) FEBS Lett. 97, 40-46

Matsushita, K., Shinagawa, E., Adachi, O. \& Ameyama, M. (1979a) J. Biochem. (Tokyo) 85, 1173-1181

Matsushita, K., Shinagawa, E., Adachi, O. \& Ameyama, M. (1979b) J. Biochem. (Tokyo) 86, 249-256

Matsushita, K., Shinagawa, E.\&Ameyama, M.(1982)Methods Enzymol. 89, 187-193

McIntire, W., Edmondson, D. E., Hopper, D. J. \& Singer, T. P. (1981) Biochemistry 20, 3068-3075

Shinagawa, E., Matsushita, K., Adachi, O. \& Ameyama, M. (1981) Agric. Biol. Chem. 45, 1079-1085

Walker, W. H. \& Singer, T. P. (1970) J. Biol. Chem. 245, 4224-4225

Walker, W. H., Singer, T. P., Ghisla, S. \& Hemmerich, P. (1972) Eur. J. Biochem. 26, 279-289 